\title{
Four New Species of the Genus Actinokineospora: Actinokineospora inagensis sp. nov., Actinokineospora globicatena sp. nov., Actinokineospora terrae sp. nov., and Actinokineospora diospyrosa sp. nov.
}

\author{
TOMOHIKO TAMURA, ${ }^{1 *}$ MASAYUKI HAYAKAWA, ${ }^{2}$ HIDEO NONOMURA, ${ }^{2}$ \\ AKIRA YOKOTA, ${ }^{1}$ AND KAZUNORI HATANO ${ }^{1}$ \\ Institute for Fermentation, Osaka, Yodogawa-ku, Osaka 532, ${ }^{1}$ and Department of Fermentation Technology, \\ Faculty of Engineering, Yamanashi University, Kofu, Yamanashi $400,{ }^{2}$ Japan
}

\begin{abstract}
The taxonomic positions of motile actinomycetes that were isolated from soil and fallen leaves obtained from around a pond and a lake and from fallen leaves of persimmons were studied. The aerial mycelia of all of the isolates exhibited fragmentation during growth, and motile spores arranged in chains were produced within the mycelia. Sporangia were not observed. These isolates contained menaquinone MK-9( $\left.\mathrm{H}_{4}\right)$, their DNA G+C contents were 69 to $70 \mathrm{~mol} \%$, they contained glutamic acid, glycine, alanine, and meso-diaminopimelic acid as cell wall amino acids, and arabinose and galactose were found in their whole-cell hydrolysates. These taxonomic characteristics are the same as those of Actinokineospora riparia. On the basis of morphological, physiological, and chemotaxonomic characteristics and DNA-DNA hybridization data, we propose the following four new species of the genus Actinokineospora for these strains: Actinokineospora inagensis for a single isolate, type strain YU4-1 ( = IFO 15663); Actinokineospora globicatena for isolates YU5-1, YU6-1, YU6-2, YU7-1, and YU7-2 (type strain, YU6-1 [= IFO 15664]); Actinokineospora terrae for a single isolate, type strain YU6-3 (= IFO 15668); and Actinokineospora diospyrosa for a single isolate, type strain YU8-1 (= IFO 15665).
\end{abstract}

Hasegawa (3) described Actinokineospora riparia as a motile arthrospore-bearing actinomycete. This organism has mesodiaminopimelic acid as a cell wall diamino acid and arabinose and galactose in its whole-cell hydrolysate, which makes it a chemotype IV organism. However, Takeuchi et al. (14) stated that the cell wall chemotype of $A$. riparia was type III/A, because arabinose was not the major sugar in the cell wall. The following five genera of motile arthrospore-bearing actinomycetes have been described previously: Sporichthya (7), Actinosynnema (4), Actinokineospora (3), Catenuloplanes (17), and Couchioplanes (15). Additional new species of the genera Sporichthya, Actinokineospora, Catenuloplanes, and Couchioplanes have not been described.

During a study of motile actinomycetes, we obtained eight isolates from soil and fallen leaves. All of these isolates formed motile arthrospores, but sporangia were not observed. These isolates contained menaquinone $\mathrm{MK}-9\left(\mathrm{H}_{4}\right)$, had DNA guanine-plus-cytosine $(\mathrm{G}+\mathrm{C})$ contents of 69 to $70 \mathrm{~mol} \%$, were phospholipid type PII organisms, had meso-diaminopimelic acid as a cell-wall diamino acid, and contained arabinose and galactose in their whole-cell hydrolysates. These morphological, physiological, and chemotaxonomic characteristics and DNA-DNA hybridization data indicated that these isolates belong to the genus Actinokineospora and are taxonomically distinct from $A$. riparia.

In this paper we describe the characterization and classification of the motile actinomycete isolates mentioned above and propose the following four new species of the genus Actinokineospora for them: Actinokineospora inagensis, Actinokineospora globicatena, Actinokineospora terrae, and Actinokineospora diospyrosa.

${ }^{*}$ Corresponding author. Mailing address: Institute for Fermentation, Osaka, 17-85, Juso-honmachi 2-chome, Yodogawa-ku, Osaka 532, Japan. Phone: 81-6-300-6555. Fax: 81-6-300-6814.

\section{MATERIALS AND METHODS}

Microorganisms and culture conditions. The strains which we used are shown in Table 1. Strains YU4-1 ${ }^{\mathrm{T}}\left(\mathrm{T}=\right.$ type strain), YU5-1, YU6-1 ${ }^{\mathrm{T}}$, YU6-2, YU6-3 ${ }^{\mathrm{T}}$, YU7-1, YU7-2, and YU8- ${ }^{\mathrm{T}}$ were isolated from soil and fallen leaves collected beside a pond and a lake and in a persimmon field in Yamanashi Prefecture, Japan, on humic acid-vitamin (HV) agar (5) by using the modified method of Makkar and Cross (9). A. riparia IFO $14541^{\mathrm{T}}$ (Institute for Fermentation, Osaka, Japan) was used as a reference strain.

Cultural observations. Cultural characteristics were recorded after 14 days of incubation at $28^{\circ} \mathrm{C}$ by the International Streptomyces Project (ISP) method (13). Colors are described below by common terms, but exact colors were determined by comparison with color chips in the Color Harmony Manual (1).

Morphological and physiological characterization. Morphological features were observed on HV agar, and physiological features were observed on media commonly used for identification of members of the order Actinomycetales (13). Motility was observed with a light microscope by using cells grown for 7 to 10

TABLE 1. Bacterial strains studied

\begin{tabular}{|c|c|c|}
\hline Strain & Source and/or other designation(s) & Species \\
\hline YU4-1 ${ }^{\mathrm{T}}$ & $\begin{array}{l}\text { Fallen leaves on the shore of a lake } \\
\text { in Yamanashi Prefecture; IFO } \\
15663^{\mathrm{T}}\end{array}$ & A. inagensis \\
\hline YU5-1 & $\begin{array}{l}\text { Soil on the shore of a lake in } \\
\text { Yamanashi Prefecture }\end{array}$ & A. globicatena \\
\hline YU6-1 ${ }^{\mathrm{T}}$ & $\begin{array}{l}\text { Soil around a pond in Yamanashi } \\
\text { Prefecture; IFO } 15664^{\mathrm{T}}\end{array}$ & A. globicatena \\
\hline YU6-2 & $\begin{array}{l}\text { Soil around a pond in Yamanashi } \\
\text { Prefecture }\end{array}$ & A. globicatena \\
\hline YU6-3 ${ }^{\mathrm{T}}$ & $\begin{array}{l}\text { Soil around a pond in Yamanashi } \\
\text { Prefecture; IFO } 15668^{\mathrm{T}}\end{array}$ & A. terrae \\
\hline YU7-1 & $\begin{array}{l}\text { Fallen leaves around a pond in } \\
\text { Yamanashi Prefecture }\end{array}$ & A. globicatena \\
\hline YU7-2 & $\begin{array}{l}\text { Fallen leaves around a pond in } \\
\text { Yamanashi Prefecture }\end{array}$ & A. globicatena \\
\hline YU8-1 ${ }^{\mathrm{T}}$ & $\begin{array}{l}\text { Fallen persimmon leaves in } \\
\text { Yamanashi Prefecture; IFO } \\
15665^{\mathrm{T}}\end{array}$ & A. diospyrosa \\
\hline IFO $14541^{\mathrm{T}}$ & ATCC $49499^{\mathbf{T}}$, JCM $7471^{\mathrm{T}}$ & A. riparia \\
\hline
\end{tabular}



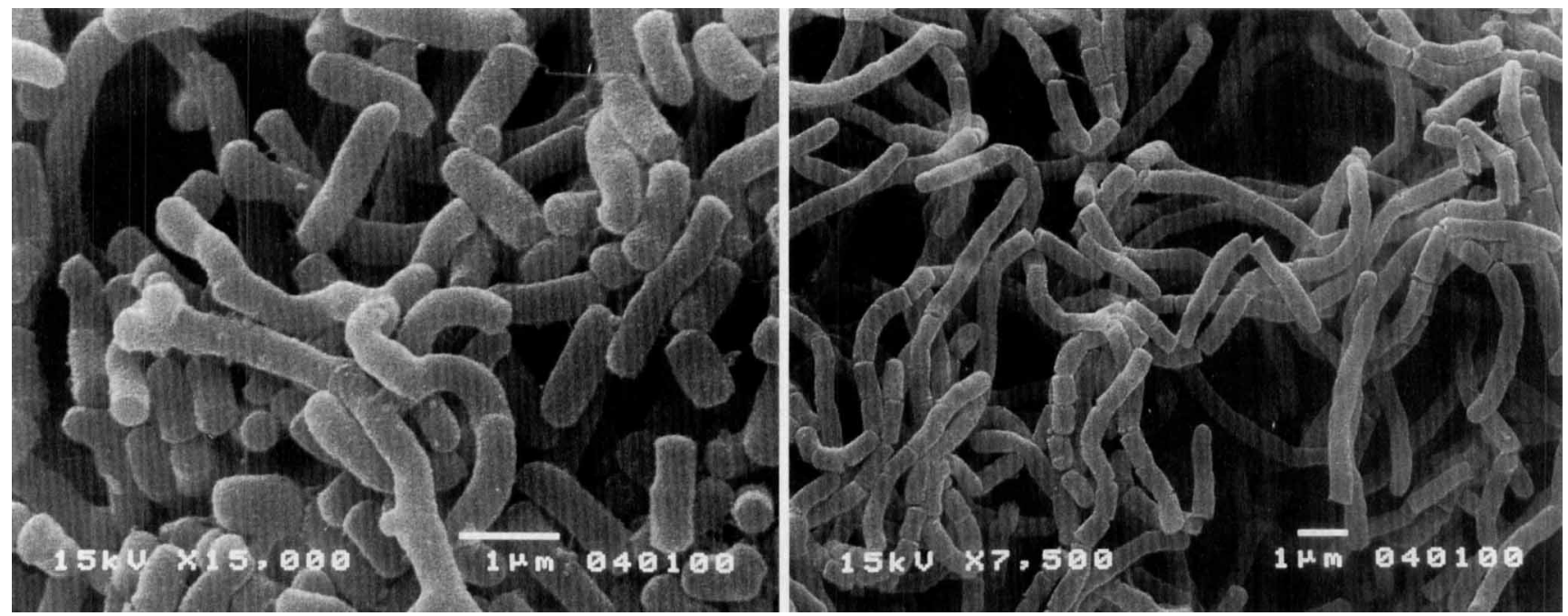

FIG. 1. Scanning electron micrographs of isolate $\mathrm{YU} 4-1^{\mathrm{T}}$ grown on $\mathrm{HV}$ agar for 10 days at $28^{\circ} \mathrm{C}$.
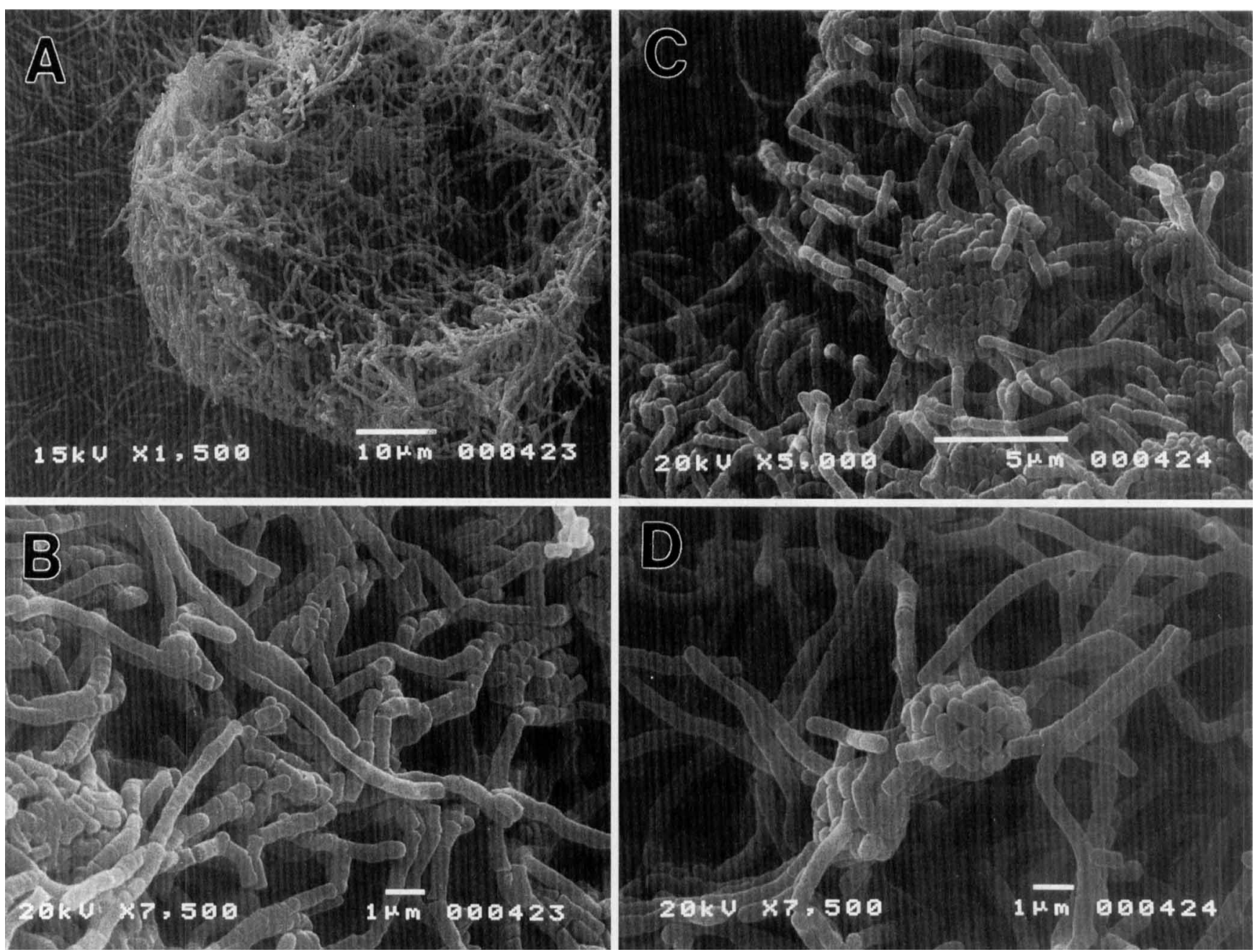

FIG. 2. Scanning electron micrographs of isolates YU6-1 ${ }^{\mathrm{T}}\left(\mathrm{A}\right.$ and B) and YU6-2 (C and D) grown on $\mathrm{HV}$ agar for 10 days at $28^{\circ} \mathrm{C}$. 

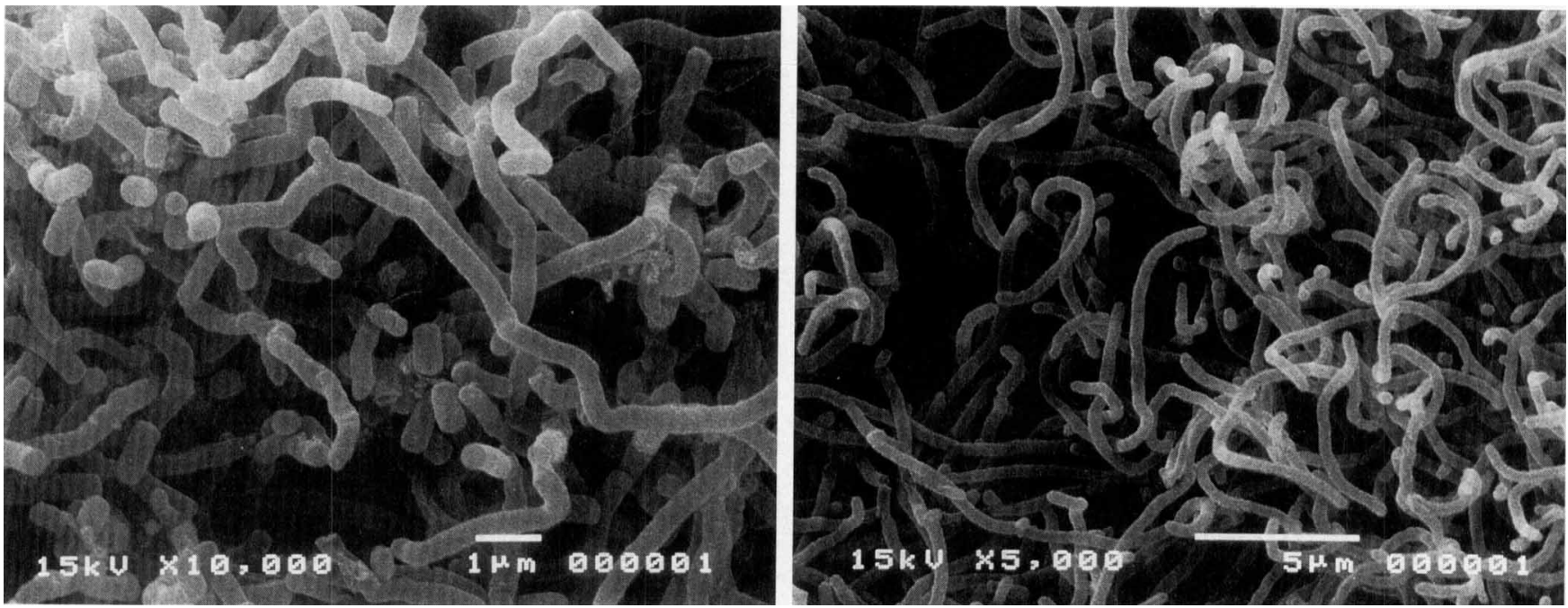

FIG. 3. Scanning electron micrographs of isolate YU6- $3^{\mathrm{T}}$ grown on $\mathrm{HV}$ agar for 10 days at $28^{\circ} \mathrm{C}$.

days at $28^{\circ} \mathrm{C}$ on $\mathrm{HV}$ agar and then incubated at $28^{\circ} \mathrm{C}$ for $1 \mathrm{~h}$ in $0.01 \mathrm{M}$ phosphate buffer ( $\mathrm{pH} 7.0$ ) containing 10\% soil extract. Cultures grown on HV agar for 14 days at $28^{\circ} \mathrm{C}$ were observed with a scanning electron microscope (model JSM5400; JEOL, Ltd.). Samples for scanning electron microscopy were prepared by cutting a block from the agar on which a culture grew, fixing the block in osmium tetroxide vapor at room temperature for $4 \mathrm{~h}$, dehydrating the cells through a graded ethanol series and then in a Hitachi model HCP-2 critical point drying apparatus, and sputter coating the preparation with palladium under a vacuum.

Freeze-dried cells for chemotaxonomic analyses were obtained from cultures grown in yeast extract-glucose broth (containing $10 \mathrm{~g}$ of yeast extract and $10 \mathrm{~g}$ of D-glucose in $1,000 \mathrm{ml}$ of distilled water; $\mathrm{pH} 7.0$ ) on a rotary shaker at $28^{\circ} \mathrm{C}$.

Analyses of chemotaxonomic characteristics. Cell wall sugar, polar lipid, cellular fatty acid, isoprenoid quinone, and peptidoglycan analyses were performed as described previously (15).

DNA base composition. DNA was obtained by the method of Saito and Miura (11). The $\mathrm{G}+\mathrm{C}$ content of DNA was determined by the method of Mesbah et al. (10) after treatment with $P_{1}$ nuclease and alkaline phosphatase, using a model LC-6AD high-performance liquid chromatography apparatus (Shimadzu Co., Ltd., Kyoto, Japan) equipped with a Cosmosil $5 \mathrm{C}_{18}$-AR column $(4.6$ by $150 \mathrm{~mm}$; Nacalai Tesque, Inc., Kyoto, Japan). The mobile phase was $0.2 \mathrm{M}$ ammonium phosphate-acetonitrile $(40: 1, \mathrm{vol} / \mathrm{vol})$.

DNA-DNA hybridization. Levels of DNA-DNA relatedness were determined fluorometrically by the method of Ezaki et al. (2), using biotinylated DNA.

\section{RESULTS AND DISCUSSION}

Morphological observations. All of the isolates were grampositive, non-acid-fast, aerobic organisms with branched hyphae and therefore belong to the order Actinomycetales Buchanan. Nonfragmenting, pale orange to tan substrate mycelia were formed. Morphological observations of 10-day-old cultures grown on HV agar revealed the presence of aerial mycelia with spore chains. The spores were rod shaped $(0.3$ to 0.5 by 0.5 to $0.8 \mu \mathrm{m}$ ) and were formed by fragmentation of the hyphae (arthrospores); the spores had smooth surfaces, as revealed by scanning electron microscopy (Fig. 1 through 4). In isolates YU5-1, YU6-1 ${ }^{\mathrm{T}}$, YU6-2, YU7-1, and YU7-2, the spore chains and aerial mycelia often aggregated into clusters resembling sporodochia (Fig. 2).

Cultural characteristics. As shown in Table 2, all of the isolates had nearly the same cultural characteristics. The colonies were yellow to orange. All of the isolates exhibited good growth on all of the media tested except peptone-yeast extract-
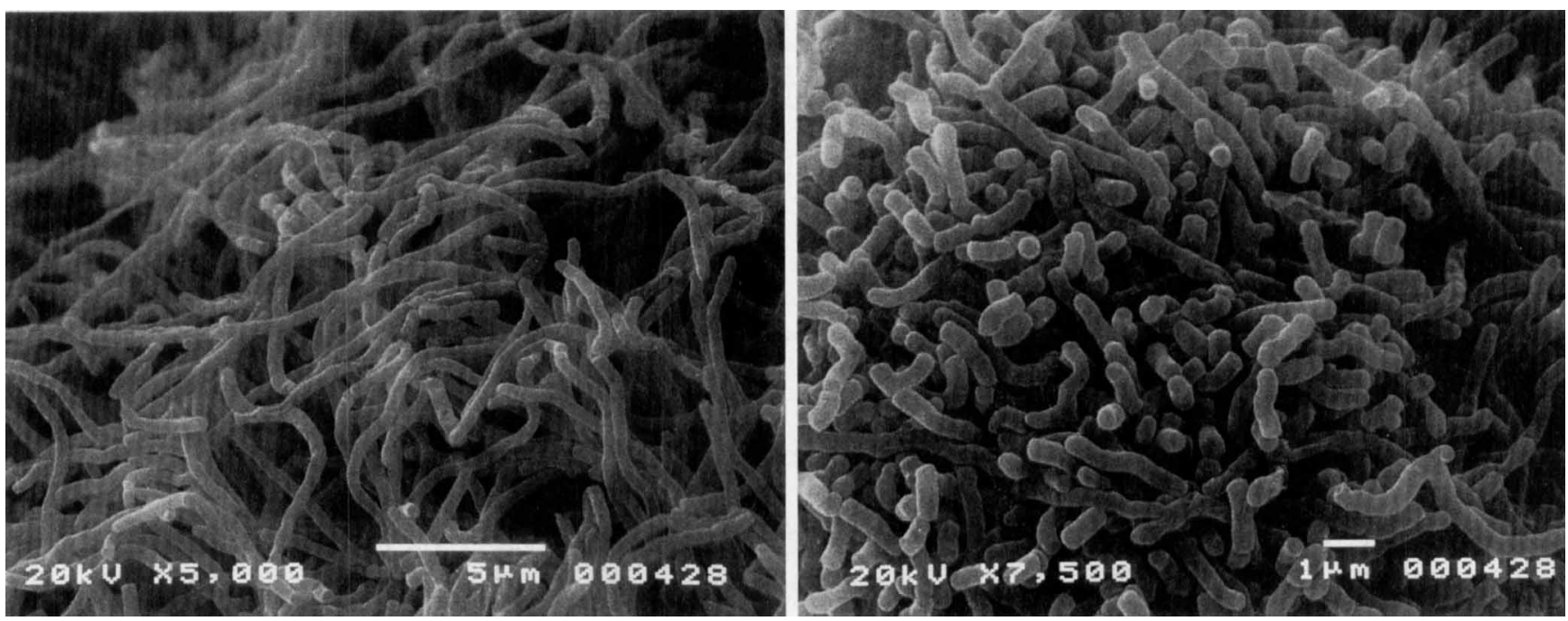

FIG. 4. Scanning electron micrographs of isolate $\mathrm{YU} 8-1^{\mathrm{T}}$ grown on $\mathrm{HV}$ agar for 10 days at $28^{\circ} \mathrm{C}$. 


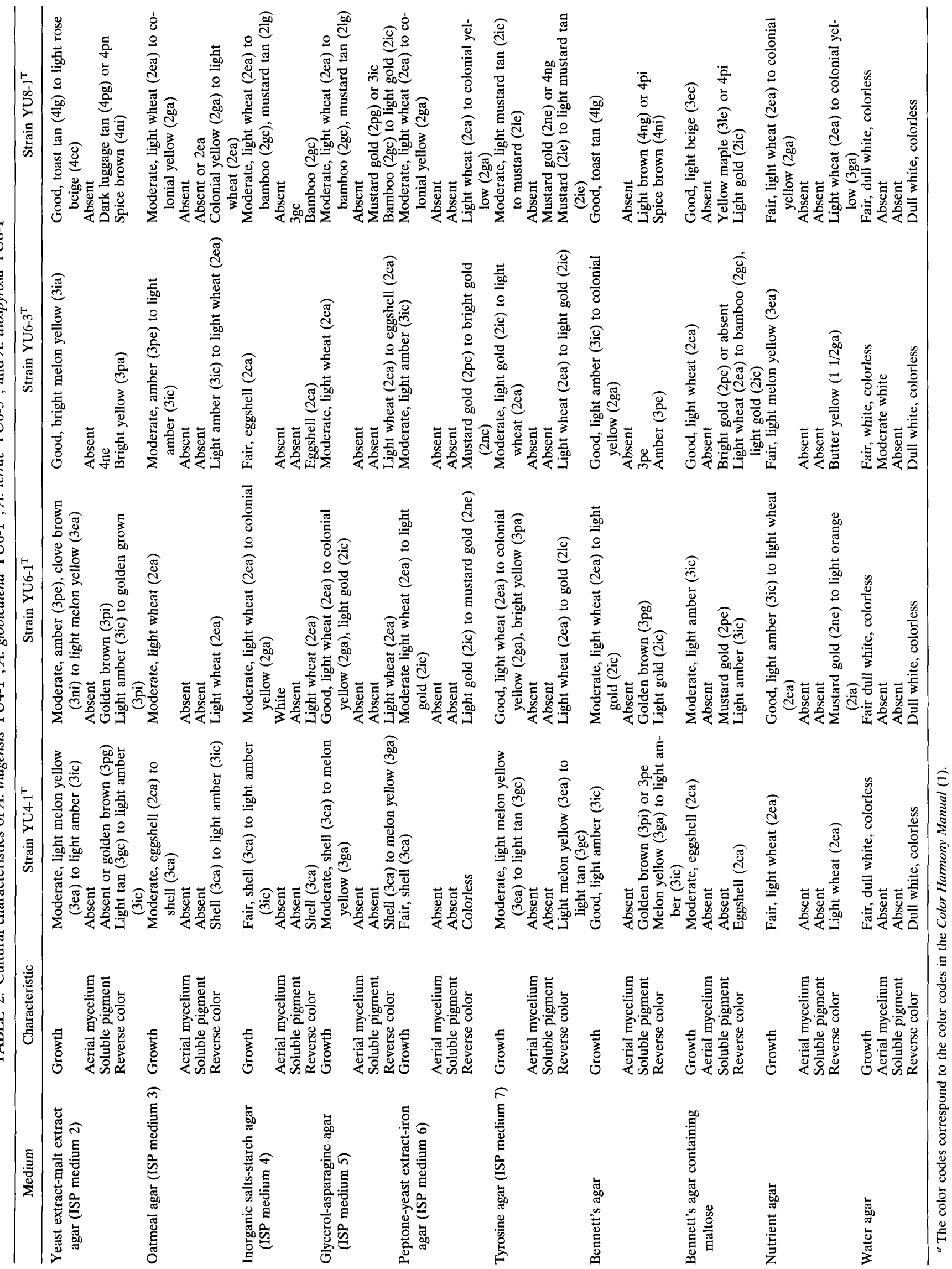


TABLE 3. Phenotypic characteristics of $A$. inagensis, $A$. globicatena, $A$. terrae, $A$. diospyrosa, and $A$. riparia strains

\begin{tabular}{|c|c|c|c|c|c|c|c|c|c|}
\hline \multirow{2}{*}{ Characteristic } & \multirow{2}{*}{$\begin{array}{l}\text { A. inagensis } \\
\text { YU4-1 }^{\mathrm{T}}\end{array}$} & \multicolumn{5}{|c|}{ A. globicatena strains } & \multirow{2}{*}{$\begin{array}{l}\text { A. terrae } \\
\text { YU6-3 }^{\mathrm{T}}\end{array}$} & \multirow{2}{*}{$\begin{array}{l}\text { A. diospyrosa } \\
\text { YU8-1 }{ }^{\mathbf{T}}\end{array}$} & \multirow{2}{*}{$\begin{array}{l}\text { A. riparia } \\
\text { IFO } 14541^{\mathrm{T}}\end{array}$} \\
\hline & & YU5-1 & YU6-1 ${ }^{\mathrm{T}}$ & YU6-2 & YU7-1 & $\overline{\text { YU7-2 }}$ & & & \\
\hline \multicolumn{10}{|l|}{ Utilization of: } \\
\hline Inositol & $--^{a}$ & - & - & - & - & - & - & _- & - \\
\hline D-Fructose & \pm & + & ++ & ++ & ++ & + & ++ & ++ & \pm \\
\hline L-Arabinose & - & \pm & \pm & - & + & + & \pm & + & - \\
\hline Sucrose & - & + & + & + & ++ & + & + & + & - \\
\hline D-Xylose & - & - & - & - & - & - & - & - & - \\
\hline D-Mannitol & - & - & - & - & - & - & - & - & _- \\
\hline Raffinose & - & - & - & - & - & - & - & - & - \\
\hline L-Rhamnose & \pm & \pm & \pm & \pm & \pm & \pm & \pm & \pm & \pm \\
\hline D-Mannose & - & + & + & + & + & + & + & \pm & \pm \\
\hline Maltose & - & \pm & + & ++ & + & + & + & + & \pm \\
\hline D-Galactose & - & - & - & - & - & - & - & - & $\bar{z}$ \\
\hline Lactose & - & - & - & - & - & - & - & - & - \\
\hline D-Sorbitol & - & - & - & - & - & - & - & - & - \\
\hline Growth temp range $\left({ }^{\circ} \mathrm{C}\right)$ & $14-33$ & $13-36$ & $11-35$ & $12-34$ & $13-34$ & $14-34$ & $12-34$ & $12-32$ & NT \\
\hline Optimum temp for growth $\left({ }^{\circ} \mathrm{C}\right)$ & $22-27$ & $23-30$ & $25-30$ & $22-29$ & $23-27$ & $22-28$ & $20-26$ & $22-29$ & NT \\
\hline Reduction of nitrate & $P$ & $\mathrm{P}$ & $P$ & $\mathrm{P}$ & $P$ & $\mathbf{P}$ & $\mathrm{P}$ & $\mathrm{P}$ & A \\
\hline Salt tolerance $(\%)$ & $<2$ & $<4$ & $<4$ & $<4$ & $<4$ & $<4$ & $<4$ & $<4$ & $<3$ \\
\hline Peptonization of milk & A & A & A & A & A & A & $P$ & $P$ & A \\
\hline \multicolumn{10}{|l|}{ Hydrolysis of: } \\
\hline Starch & A & $\mathrm{P}$ & $\mathbf{P}$ & $\mathbf{P}$ & $\mathbf{P}$ & $\mathrm{P}$ & $\mathbf{P}$ & $P$ & A \\
\hline Gelatin & A & $\mathrm{P}$ & $P$ & $\mathrm{P}$ & $\mathbf{P}$ & $P$ & $P$ & $\mathbf{P}$ & A \\
\hline Cellulose & A & A & A & A & A & A & A & A & A \\
\hline Decomposition of calcium malate & A & $\mathrm{P}$ & $P$ & $P$ & $P$ & $\mathbf{P}$ & $\mathrm{P}$ & A & A \\
\hline
\end{tabular}

${ }^{a}-$, none; ++ , good; + , moderate; \pm , poor; P, present; A, absent; NT, not tested.

iron agar (ISP medium 6) and water agar. All of the isolates produced a soluble pigment on Bennett's agar and yeast extract-malt extract agar (ISP medium 2). All of the isolates except isolate YU4-1 ${ }^{\mathrm{T}}$ produced soluble pigments on Bennett's agar containing maltose. Isolates YU7-1 and YU8 $-1^{\mathrm{T}}$ produced a soluble pigment on glycerol-asparagine agar (ISP medium 5) and tyrosine agar (ISP medium 7).

Physiological and biochemical characteristics. Biochemical properties of the isolates are shown in Table 3. All of the new isolates reduced nitrate, but IFO $14541^{\mathrm{T}}$ did not. All of the strains except YU4-1 ${ }^{\mathrm{T}}$ and IFO $14541^{\mathrm{T}}$ liquefied gelatin. Isolates YU5-1, YU6-1 ${ }^{\mathrm{T}}$, YU6-2, YU6-3 ${ }^{\mathrm{T}}$, YU7-1, and YU7-2 solubilized calcium malate.

Chemotaxonomic characteristics. The whole-cell sugar patterns, cell wall amino acid compositions, phospholipid types, menaquinone compositions, and cellular fatty acid compositions of the isolates are shown in Tables 4 through 6 . The cell walls of the isolates contained meso-diaminopimelic acid, glycine, D-glutamic acid, and L-alanine, indicating that the peptidoglycan type of these organisms is type $\mathrm{A} 1 \gamma$ as described by Schleifer and Kandler (12). All of the isolates contained galactose and glucose as their major whole-cell sugars in addition to small amounts of arabinose, mannose, and rhamnose, indicating that the whole-cell sugar pattern of these isolates is pattern A as described by Lechevalier and Lechevalier (6). All of the isolates contained galactose as the major cell wall sugar, as well as trace to small amounts of arabinose (data not shown). The major menaquinone was $\mathrm{MK}-9\left(\mathrm{H}_{4}\right)$, and small amounts of MK-7 $\left(\mathrm{H}_{4}\right)$ and MK- $8\left(\mathrm{H}_{4}\right)$ were also present (Table 5). Although Hasegawa (3) identified the major menaquinone of $A$. riparia IFO $14541^{\mathrm{T}}$ as MK-10 $\left(\mathrm{H}_{0}\right)$, a gas-liquid chromatography-mass spectrometry study indicated that it was MK$9\left(\mathrm{H}_{4}\right)(5 \mathrm{a})$. All of the isolates contained iso- $\mathrm{C}_{16: 0}$ as the major cellular fatty acid, as well as smaller amounts of iso- $\mathrm{C}_{15: 0}, \mathrm{C}_{16: 0}$,

TABLE 4. Cell wall amino acid and whole-cell sugar compositions of strains of five Actinokineospora species ${ }^{a}$

\begin{tabular}{|c|c|c|c|c|c|c|c|c|c|c|c|c|}
\hline \multirow{2}{*}{ Strain } & \multicolumn{5}{|c|}{ Amino acid composition of peptidoglycan (molar ratio) ${ }^{b}$} & \multicolumn{7}{|c|}{ Sugar composition of whole cells } \\
\hline & Glu & Mur & Gly & Ala & meso-DAP & GlcN & Rha & Man & Ara & Gal & Xyl & Glc \\
\hline$\overline{\text { YU4-1 }^{\mathrm{T}}}$ & 1.00 & 0.43 & 1.31 & 2.09 & 0.72 & $t^{c}$ & + & + & + & $+t$ & - & + \\
\hline YU5-1 & 1.00 & 0.55 & 0.87 & 1.77 & 0.48 & + & + & + & + & ++ & - & ++ \\
\hline YU6-1 ${ }^{\mathrm{T}}$ & 1.00 & 0.75 & 1.43 & 2.34 & 0.87 & + & + & + & + & ++ & - & ++ \\
\hline YU6-2 & 1.00 & 0.48 & 1.33 & 2.30 & 0.94 & + & + & + & + & ++ & - & ++ \\
\hline YU6-3 & 1.00 & 0.74 & 1.62 & 2.17 & 0.61 & + & + & + & + & + & - & + \\
\hline YU7-1 & 1.00 & 0.53 & 1.56 & 2.55 & 1.15 & + & + & + & + & ++ & - & ++ \\
\hline YU7-2 & 1.00 & 0.54 & 1.20 & 2.15 & 0.51 & + & + & + & + & ++ & - & ++ \\
\hline YU8-1 ${ }^{\mathrm{T}}$ & 1.00 & 0.54 & 0.70 & 2.37 & 0.87 & + & + & + & + & ++ & - & ++ \\
\hline IFO $14541^{T}$ & 1.00 & 0.39 & 1.51 & 1.73 & 1.19 & + & + & + & + & ++ & - & ++ \\
\hline
\end{tabular}

${ }^{a}$ Abbreviations: Glu, glutamic acid; Mur, muramic acid; Gly, glycine; Ala, alanine; meso-DAP, meso-diaminopimelic acid; GlcN, glucosamine; Rha, rhamnose; Man, mannose; Ara, arabinose; Gal, galactose; Xyl, xylose; Glc, glucose.

${ }^{b}$ Calculated by defining the amount of glutamic acid as 1.0 .

${ }^{c}+$, present (minor peak); ++ , present (major peak); -, absent. 
TABLE 5. Phospholipid types and menaquinone compositions of strains of five Actinokineospora species

\begin{tabular}{|c|c|c|c|c|c|c|c|}
\hline \multirow{2}{*}{ Strain } & \multirow{2}{*}{$\begin{array}{l}\text { Phospholipid } \\
\text { types }^{a}\end{array}$} & \multicolumn{6}{|c|}{ Menaquinone composition } \\
\hline & & $\mathrm{MK}-7\left(\mathrm{H}_{4}\right)$ & MK-8 $\left(\mathrm{H}_{2}\right)$ & MK-8( $\left(\mathrm{H}_{4}\right)$ & MK-9 $\left(\mathrm{H}_{0}\right)$ & MK-9( $\left.\mathrm{H}_{2}\right)$ & MK-9(H \\
\hline YU4-1 ${ }^{\mathrm{T}}$ & PII & $+^{b}$ & $\operatorname{tr}$ & $\operatorname{tr}$ & $\operatorname{tr}$ & & +++ \\
\hline YU5-1 & PII & & & & & & +++ \\
\hline YU6-1 ${ }^{T}$ & PII & $\operatorname{tr}$ & & $\operatorname{tr}$ & & & +++ \\
\hline YU6-2 & PII & + & & + & & & +++ \\
\hline YU6-3 ${ }^{\mathrm{T}}$ & PII & + & & + & $\operatorname{tr}$ & $\operatorname{tr}$ & +++ \\
\hline YU7-1 & PII & $\operatorname{tr}$ & & tr & & & +++ \\
\hline YU7-2 & PII & & & + & & & +++ \\
\hline YU8-1 ${ }^{\mathrm{T}}$ & PII & & & + & & & +++ \\
\hline IFO $14541^{\mathrm{T}}$ & PII & + & & & $\operatorname{tr}$ & & +++ \\
\hline
\end{tabular}

${ }^{a}$ Phosphatidylethanolamine was detected, but phosphatidylglycerol, an unidentified phospholipid, and phosphatidylcholine were not detected.

${ }^{b}+++,>50 \% ;++,>10 \% ;+, \leq 10 \%$; tr, trace.

and $\mathrm{C}_{16: 1}$ (Table 6). Mycolic acids were absent. Phosphatidylethanolamine was detected, but phosphatidylglycerol, an unidentified phospholipid, and phosphatidylcholine were not detected; this pattern corresponds to phospholipid type II of Lechevalier et al. (8). The $\mathrm{G}+\mathrm{C}$ contents of the DNAs were 68.9 to $70.0 \mathrm{~mol} \%$ (Table 7).

DNA-DNA hybridization. As shown in Table 7, DNA-DNA hybridization studies indicated that the eight isolates and $A$. riparia IFO $14541^{\mathrm{T}}$ can be divided into five groups on the basis of DNA relatedness data. The first group has a single member, isolate $\mathrm{YU} 4-1^{\mathrm{T}}$; the second group contains five isolates, YU5-1, YU6-1 ${ }^{\mathrm{T}}$, YU6-2, YU7-1, and YU7-2; the third and fourth groups each contain a single isolate (YU6-3 ${ }^{\mathrm{T}}$ and YU8$1^{\mathrm{T}}$, respectively); and the fifth group is a single-member group containing $A$. riparia IFO $14541^{\mathrm{T}}$. The levels of DNA relatedness between isolate YU4-1 ${ }^{\mathrm{T}}$ and members of other groups were less than 29\%; the levels of DNA relatedness among isolates YU5-1, YU6-1 ${ }^{\mathrm{T}}$, YU6-2, YU7-1, and YU7-2 were more than 72\%; the levels of DNA relatedness between isolate YU6- $3^{\mathrm{T}}$ and isolates belonging to the second group ranged from 29 to $57 \%$; the levels of DNA relatedness between isolate YU8- $1^{\mathrm{T}}$ and members of other groups were less than $33 \%$; and the levels of DNA relatedness between IFO $14541^{\mathrm{T}}$ and all of the other isolates were less than $35 \%$.

Our isolates form aerial mycelia with motile arthrospores, have meso-diaminopimelic acid as a cell wall diamino acid, contain arabinose and galactose in their whole-cell hydrolysates, have MK-9( $\left.\mathrm{H}_{4}\right)$ as their major menaquinone, and are phospholipid type II organisms. Therefore, these isolates are considered members of the genus Actinokineospora. On the basis of their biochemical characteristics and DNA-DNA similarity values, they can readily be distinguished from $A$. riparia IFO $14541^{\mathrm{T}}$.

Therefore, we propose the following classification: isolate YU4-1 (= IFO 15563) is the type strain of Actinokineospora inagensis sp. nov.; isolates YU5-1, YU6-1 ${ }^{\mathrm{T}}\left(=\mathrm{IFO} 15564^{\mathrm{T}}\right)$, YU6-2, YU7-1, and YU7-2 are members of Actinokineospora globicatena sp. nov.; isolate YU6-3 (= IFO 15668) is the type strain of Actinokineospora terrae sp. nov.; and isolate YU8-1 (= IFO 15565) is the type strain of Actinokineospora diospyrosa sp. nov. Differential characteristics of these four species and $A$. riparia are summarized in Table 8.

Species of the genera Sporichthya, Actinosynnema, Actinokineospora, Catenuloplanes, and Couchioplanes have been described previously as actinomycetes that form motile arthrospores. On the basis of the results of a comparative analysis of 16S ribosomal DNA sequences, the genera Catenuloplanes and Couchioplanes were placed in the family Micromonosporaceae (15), and it was found that the genus Actinokineospora is closely related to species of the genus Saccharothrix, but should not be placed in the family Pseudonocardiaceae (16). Previous taxonomic studies of the genus Actinokineospora have been carried out with a single strain of a single species, $A$. riparia. The new species described below might be of help in more detailed studies on the phylogenetic positions of these organisms. Additional studies, including a comparative analysis of

TABLE 6. Cellular fatty acid compositions of strains of five Actinokineospora species

\begin{tabular}{|c|c|c|c|c|c|c|c|c|c|c|c|c|c|c|c|c|c|c|}
\hline \multirow{3}{*}{ Strain } & \multicolumn{18}{|c|}{ Fatty acid composition } \\
\hline & \multicolumn{16}{|c|}{ Nonpolar fatty acids } & \multicolumn{2}{|c|}{$\begin{array}{c}\text { iso-branched } 2-\mathrm{OH} \\
\text { fatty acids }\end{array}$} \\
\hline & $\begin{array}{c}\text { anteiso- } \\
\mathrm{C}_{17: 0}\end{array}$ & iso- $\mathrm{C}_{14: 0}$ & iso- $\mathrm{C}_{15: 0}$ & iso- $\mathrm{C}_{16: 0}$ & iso- $\mathrm{C}_{17: 0}$ & iso- $\mathrm{C}_{18: 0}$ & $\mathrm{C}_{14: 0}$ & $\mathrm{C}_{15: 0}$ & $\mathrm{C}_{16 ; 0}$ & $\mathrm{C}_{17: 0}$ & $C_{18: 0}$ & $\mathrm{C}_{15: 1}$ & $\mathrm{C}_{16: 1}$ & $\mathrm{C}_{17: 1}$ & $\mathrm{C}_{18: 1}$ & $\begin{array}{c}10 \text {-methyl- } \\
\mathrm{C}_{16}\end{array}$ & iso- $\mathrm{C}_{15: 0}$ & iso- $\mathrm{C}_{16: 0}$ \\
\hline YU4-1 $^{\mathrm{T}}$ & $2.4^{a}$ & 1.2 & 9.4 & 61.3 & 4.6 & & 0.1 & 0.5 & 8.9 & 0.6 & & 0.4 & 4.4 & 0.7 & 0.3 & 2.3 & $\pm^{b}$ & ++ \\
\hline YU5-1 & 5.7 & 1.2 & 14.9 & 35.8 & 5.2 & 0.4 & 0.4 & 0.4 & 17.0 & 2.2 & 1.0 & & 10.0 & 1.2 & 0.5 & 3.7 & + & ++ \\
\hline YU6-1 $^{\mathrm{T}}$ & 3.5 & 1.1 & 17.9 & 38.1 & 8.1 & 0.8 & 0.3 & 0.4 & 12.7 & 3.5 & & & 10.8 & 1.8 & & & + & ++ \\
\hline YU6-2 & 2.4 & 1.8 & 19.8 & 35.0 & 9.4 & 0.5 & 0.3 & 0.6 & 15.0 & 2.8 & 0.6 & & 10.5 & & & & + & ++ \\
\hline YU6-3 $3^{T}$ & 5.1 & 1.6 & 18.2 & 38.6 & 6.3 & & 0.2 & 0.1 & 12.5 & 3.6 & & & 4.3 & 2.2 & & 2.9 & + & ++ \\
\hline YU7-1 & 4.1 & 1.7 & 18.4 & 39.2 & 8.2 & & 0.3 & 0.5 & 12.4 & 3.2 & & & 8.3 & 2.3 & 0.7 & & + & $+t$ \\
\hline YU7-2 & 4.0 & 1.3 & 13.8 & 38.4 & 4.6 & 0.2 & 0.4 & 0.5 & 17.5 & 2.7 & 0.9 & & 12.5 & 1.7 & 0.5 & & + & ++ \\
\hline YU8-1 ${ }^{\mathrm{T}}$ & 4.7 & 1.6 & 20.3 & 36.5 & 11.1 & & & 0.8 & 12.6 & 3.6 & 0.5 & & 1.5 & 1.6 & 0.4 & 3.7 & + & ++ \\
\hline IFO $14541^{\mathrm{T}}$ & 7.3 & 2.2 & 16.7 & 43.1 & 3.9 & & 0.3 & 1.1 & 8.0 & 2.4 & 0.3 & & 2.3 & 1.0 & & 5.2 & + & ++ \\
\hline
\end{tabular}

${ }^{a}$ The values are the percentages of the nonpolar fatty acids.

${ }^{b} \pm,<10 \% ;+, 10$ to $30 \%$;,$++>30 \%$. 
TABLE 7. G+C contents and levels of DNA relatedness among strains of five Actinokineospora species

\begin{tabular}{|c|c|c|c|c|c|c|c|c|c|c|}
\hline \multirow{2}{*}{ Strain } & \multirow{2}{*}{$\begin{array}{c}\mathrm{G}+\mathrm{C} \text { content } \\
(\mathrm{mol} \%)\end{array}$} & \multicolumn{9}{|c|}{$\%$ of DNA complementary to labelled DNA from strain: } \\
\hline & & YU4-1 ${ }^{\mathrm{T}}$ & YU5-1 & YU6-1 ${ }^{\mathrm{T}}$ & YU6-2 & YU6-3 $^{\mathrm{T}}$ & YU7-1 & YU7-2 & YU8-1 ${ }^{\mathrm{T}}$ & IFO $14541^{\mathrm{T}}$ \\
\hline 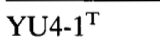 & 69.1 & 100 & 10 & 15 & 6 & 14 & 3 & 8 & 9 & 9 \\
\hline YU5-1 & 69.8 & 23 & 100 & 108 & 84 & 55 & 97 & 93 & 28 & 12 \\
\hline YU6-1 ${ }^{\mathrm{T}}$ & 69.7 & 19 & 100 & 100 & 92 & 52 & 110 & 86 & 28 & 3 \\
\hline YU6-2 & 69.8 & 15 & 75 & 100 & 100 & 41 & 87 & 72 & 27 & 7 \\
\hline YU6- $3^{\mathrm{T}}$ & 70.0 & 12 & 41 & 41 & 38 & 100 & 44 & 29 & 33 & 8 \\
\hline YU7-1 & 69.5 & 18 & 102 & 121 & 91 & 57 & 100 & 85 & 25 & 35 \\
\hline YU7-2 & 69.8 & 25 & 115 & 115 & 95 & 54 & 91 & 100 & 33 & 12 \\
\hline YU8-1 ${ }^{\mathrm{T}}$ & 69.3 & 29 & 29 & 39 & 21 & 37 & 17 & 30 & 100 & 27 \\
\hline IFO $14541^{\mathrm{T}}$ & 68.9 & 10 & 3 & 5 & 3 & 6 & 2 & 7 & 6 & 100 \\
\hline
\end{tabular}

$16 \mathrm{~S}$ rRNA sequences, will be performed to determine the relationship of the genus Actinokineospora to other actinomycetes which have motile arthrospores.

Description of Actinokineospora inagensis sp. nov. Actinokineospora inagensis (in.ag.en'sis. M. L. adj. inagensis, pertaining to Lake Inaga, the lake from which the organism was isolated) is a gram-positive, non-acid-fast, aerobic organism with branching hyphae. Nonfragmenting, yellow to tan vegetative mycelia are present. Spores are formed in chains containing several members and are motile. The spores are oval or short rods (diameter, 1.3 to $2.0 \mu \mathrm{m}$ ) and exhibit motility when they are suspended in sterile distilled water. Strictly aerobic. The temperature range for growth is 14 to $33^{\circ} \mathrm{C}$, and good growth occurs at temperatures between 22 and $27^{\circ} \mathrm{C}$. The organism grows well on Bennett's agar. In general, the vegetative mycelia are yellow to tan, and the aerial mycelia are white to gray. Hydrogen sulfide is produced. Reduces nitrate to nitrite. Gelatin liquefaction negative. Does not hydrolyze starch. Does not decompose calcium malate. Does not grow in the presence of $2 \% \mathrm{NaCl}$. Peptonization of milk is negative. Fructose and rhamnose are slightly utilized as carbon sources, but inositol, arabinose, sucrose, xylose, mannitol, raffinose, mannose, maltose, galactose, lactose, and glucitol are not utilized.

Cell walls contain glutamic acid, glycine, alanine, and mesodiaminopimelic acid (molar ratio, ca. 1:1:2:1). The peptidoglycan type is type A (probably A1 $\gamma$ ) according to the classification of Schleifer and Kandler (12). Arabinose and galactose are the characteristic whole-cell sugars. iso-Hexadecanoic acid (iso- $\mathrm{C}_{16: 0}$ ) is the major cellular fatty acid. The $\mathrm{G}+\mathrm{C}$ content of the DNA of the type strain is $69.1 \mathrm{~mol} \%$. The major menaquinone is MK-9( $\left.\mathrm{H}_{4}\right)$, and a small amount of MK-7 $\left(\mathrm{H}_{4}\right)$ is also present. Phosphatidylethanolamine is the diagnostic phospho-

TABLE 8. Differential characteristics of Actinokineospora species

\begin{tabular}{|c|c|c|c|c|c|}
\hline Characteristic & A. riparia & A. inagensis & $\begin{array}{l}\text { A. globi- } \\
\text { catena }\end{array}$ & A. terrae & $\begin{array}{l}\text { A. dio- } \\
\text { spyrosa }\end{array}$ \\
\hline \multicolumn{6}{|l|}{ Utilization of: } \\
\hline Sucrose & $-{ }^{a}$ & - & + & + & + \\
\hline D-Mannose & \pm & - & + & + & + \\
\hline Reduction of nitrate & - & + & + & + & + \\
\hline Growth in $\mathrm{NaCl}(\%)$ & $<3$ & $<2$ & $<4$ & $<4$ & $<4$ \\
\hline Peptonization of milk & - & - & - & + & + \\
\hline \multicolumn{6}{|l|}{ Hydrolysis of: } \\
\hline Starch & - & - & + & + & + \\
\hline Gelatin & - & - & + & + & + \\
\hline $\begin{array}{l}\text { Decomposition of } \\
\text { calcium malate }\end{array}$ & - & - & + & + & - \\
\hline Formation of clusters & - & - & + & - & - \\
\hline
\end{tabular}

${ }^{a}-$, none; ++ , good; + , moderate; \pm , poor. lipid, and phosphatidylglycerol, phosphatidylcholine, and an unidentified phospholipid are absent (type PII). Habitat: fallen leaves.

The type strain is IFO 15663 (= YU4-1).

Description of Actinokineospora globicatena sp. nov. Actinokineospora globicatena (glo.bi.ca.te'na. L. n. globus, a ball, sphere; L. n. catena, chain; globicatena, ball of chains, referring to the mass of spore chains that aggregate into balls). Morphological, physiological, and chemotaxonomic characteristics are the same as those given above for $A$. inagensis. In addition, the spore chains and aerial mycelia often aggregate into clusters. The organism grows well on yeast extract-malt extract agar (ISP medium 2), glycerol-asparagine agar (ISP medium 5), tyrosine agar (ISP medium 7), Bennett's agar, and Bennett's agar containing maltose. The temperature range for growth is 11 to $36^{\circ} \mathrm{C}$, and good growth occurs at temperatures between 20 and $30^{\circ} \mathrm{C}$. In general, the vegetative mycelia of the strains are yellow to golden brown, and the aerial mycelia are white to gray. Gelatin liquefaction positive. Hydrolyzes starch. Decomposes calcium malate. Does not grow in the presence of $4 \% \mathrm{NaCl}$. Peptonization of milk is negative. Fructose, arabinose, sucrose, mannose, maltose, and rhamnose are utilized as carbon sources, but inositol, xylose, mannitol, raffinose, galactose, lactose, and glucitol are not utilized.

The $\mathrm{G}+\mathrm{C}$ content of the DNA ranges from 69.5 to 69.8 mol\%; the $\mathrm{G}+\mathrm{C}$ content of the DNA of the type strain is 69.7 mol\%. The major menaquinone is MK- $9\left(\mathrm{H}_{4}\right)$. Habitat: soil and fallen leaves.

The type strain is IFO 15664 (= YU6-1).

Description of Actinokineospora terrae sp. nov. Actinokineospora terrae (ter'rae. M. L. gen. n. terrae, of the earth). Morphological, physiological, and chemotaxonomic characteristics are the same as those given above for $A$. inagensis. In addition, the organism grows well on yeast extract-malt extract agar (ISP medium 2), glycerol-asparagine agar (ISP medium 5), tyrosine agar (ISP medium 7), Bennett's agar, and Bennett's agar containing maltose. The temperature range for growth is 11 to $36^{\circ} \mathrm{C}$, and good growth occurs at temperatures between 20 and $30^{\circ} \mathrm{C}$. In general, the vegetative mycelia are yellow to golden brown, and the aerial mycelia are white to gray. Gelatin liquefaction positive. Hydrolyzes starch. Decomposes calcium malate. Does not grow in the presence of $4 \% \mathrm{NaCl}$. Peptonization of milk is positive. Fructose, arabinose, sucrose, mannose, maltose, and rhamnose are slightly utilized as carbon sources, but inositol, xylose, mannitol, raffinose, galactose, lactose, and glucitol are not utilized.

The $\mathrm{G}+\mathrm{C}$ content of the DNA is $70.0 \mathrm{~mol} \%$. The major menaquinone is MK-9 $\left(\mathrm{H}_{4}\right)$. Habitat: soil and fallen leaves.

The type strain is IFO 15668 (= YU6-3). 
Description of Actinokineospora diospyrosa sp. nov. Actinokineospora diospyrosa (di.o.spy'ros.a. M. L. adj. diospyrosa, pertaining to the fruit tree Diospyros kaki). Morphological, physiological, and chemotaxonomic characteristics are the same as those given above for $A$. inagensis. In addition, the organism grows well on yeast extract-malt extract agar (ISP medium 2), Bennett's agar, and Bennett's agar containing maltose. The temperature range for growth is 12 to $32^{\circ} \mathrm{C}$, and good growth occurs at temperatures between 22 and $29^{\circ} \mathrm{C}$. In general, the vegetative mycelia are tan, and the aerial mycelia are white to gray. Gelatin liquefaction positive. Hydrolyzes starch. Does not decompose calcium malate. Does not grow in the presence of $4 \% \mathrm{NaCl}$. Peptonization of milk is positive. Fructose, arabinose, sucrose, mannose, maltose, and rhamnose are slightly utilized as carbon sources, but inositol, xylose, mannitol, raffinose, galactose, lactose, and glucitol are not utilized.

The $\mathrm{G}+\mathrm{C}$ content of the DNA of the type strain is 69.3 mol\%. The major menaquinone is $\mathrm{MK}-9\left(\mathrm{H}_{4}\right)$, and a small amount of MK-8 $\left(\mathrm{H}_{4}\right)$ is also present. Habitat: fallen leaves.

The type strain is IFO 15665 (= YU8-1).

\section{ACKNOWLEDGMENTS}

We thank Toru Hasegawa, Institute for Fermentation, Osaka, for his encouragement and support. We also thank Takuji Kudo for supplying the mass spectrum data for $A$, riparia menaquinones.

\section{REFERENCES}

1. Container Corporation of America. 1958. Color harmony manual, 4th ed. Container Corporation of America, Chicago.

2. Ezaki, T., Y. Hashimoto, and E. Yabuuchi. 1989. Fluorometric deoxyribonucleic acid-deoxyribonucleic acid hybridization in microdilution wells as an alternative to membrane filter hybridization in which radioisotopes are used to determine genetic relatedness among bacterial strains. Int. J. Syst. Bacteriol. 39:224-229.
3. Hasegawa, T. 1988. Actinokineospora: a new genus of the Actinomycetales. Actinomycetologica $2: 31-45$.

4. Hasegawa, T., M. P. Lechevalier, and H. A. Lechevalier. 1978. New genus of the Actinomycetales: Actinosynnema gen. nov. Int. J. Syst. Bacteriol. 28:304-310.

5. Hayakawa, M., and H. Nonomura. 1987. Humic acid-vitamin agar, a new medium for selective isolation of soil actinomycetes. J. Ferment. Technol. 65:501-509.

5a.Kudo, T. Unpublished data.

6. Lechevalier, M. P., and H. A. Lechevalier. 1970. Chemical composition as a criterion in the classification of aerobic actinomycetes. Int. J. Syst. Bacteriol. 20:435-443.

7. Lechevalier, M. P., H. A. Lechevalier, and P. E. Holbert. 1968. Sporichthya, un nouveau genre de Streptomycetaceae. Ann. Inst. Pasteur (Paris) 114:277-286.

8. Lechevalier, M. P., A. E. Stern, and H. A. Lechevalier. 1981. Phospholipids in the taxonomy of actinomycetes. Zentralbl. Bakteriol. Mikrobiol. Hyg. Abt. 1 Suppl. 11:111-116.

9. Makkar, N. S., and T. Cross. 1982. Actinoplanetes in soil and on plant litter from freshwater habitats. J. Appl. Bacteriol. 52:209-218.

10. Mesbah, M., U. Premachandran, and W. B. Whitman. 1989. Precise measurement of the $\mathrm{G}+\mathrm{C}$ content of deoxyribonucleic acid by high-performance liquid chromatography. Int. J. Syst. Bacteriol. 39:159-167.

11. Saito, H., and K. Miura. 1963. Preparation of transforming deoxyribonucleic acid by phenol treatment. Biochim. Biophys. Acta 72:619-629.

12. Schleifer, K. H., and O. Kandler. 1972. Peptidoglycan types of bacterial cell walls and their taxonomic implications. Bacteriol. Rev. 36:407-477.

13. Shirling, E. B., and D. Gottlieb. 1966. Methods for characterization of Streptomyces species. Int. J. Syst. Bacteriol. 16:313-340.

14. Takeuchi, M., T. Nishii, and A. Yokota. 1992. Taxonomic significance of arabinose in the family Pseudonocardiaceae. Actinomycetologica 6:79-90.

15. Tamura, T., Y. Nakagaito, T. Nishii, T. Hasegawa, E. Stackebrandt, and A. Yokota. 1994. A new genus of the order Actinomycetales, Couchioplanes gen. nov., with descriptions of Couchioplanes caeruleus (Horan and Brodsky 1986) comb. nov. and Couchioplanes caeruleus subsp. azureus subsp. nov. Int. J. Syst. Bacteriol. 44:193-203.

16. Warwick, S., T. Bowen, H. McVeigh, and T. M. Embley. 1994. A phylogenetic analysis of the family Pseudonocardiaceae and the genera Actinokineospora and Saccharothrix with 16S rRNA sequences and a proposal to combine the genera Amycolata and Pseudonocardia in an emended genus Pseudonocardia. Int. J. Syst. Bacteriol. 44:293-299.

17. Yokota, A., T. Tamura, T. Hasegawa, and L. H. Huang. 1993. Catenuloplanes japonicus gen. nov., sp. nov., nom. rev., a new genus of the order Actinomycetales. Int. J. Syst. Bacteriol. 43:805-812. 